\title{
Durabilidad de ladrillos cerámicos reforzados con polvo de granito
}

\section{Durability of fired clay bricks containing granite powder}

\author{
G. C. Xavier ${ }^{(*)}$, F. Saboya(*), P. C. Maia(*), J. Alexandre(*)
}

Recepción/Received: 23-06-10

Aceptación/Accepted: $29-10-10$

RESUMEN

En las últimas décadas se han publicado cientos de artículos sobre las ventajas de incluir polvo de roca como materia prima en la fabricación de los ladrillos cerámicos. Sin embargo, la durabilidad y el comportamiento a largo plazo del producto final han sido objeto de pocas investigaciones. Por lo general, los ladrillos cerámicos empleados en la construcción en los países en vías de desarrollo se cuecen a temperaturas bajas, lo que impide el desarrollo de sus propiedades mecánicas. Esto queda especialmente patente cuando las condiciones ambientales son severas, en cuyo caso la meteorización puede provocar un deterioro importante. En este artículo se describe el efecto de la meteorización en ladrillos cerámicos que incorporaban entre un 0 y un $10 \%$ de polvo de granito, que es un derivado industrial. Las probetas se cocieron a 500,700 o $900{ }^{\circ} \mathrm{C}$ y luego se sometieron a condiciones ambientales naturales o a un proceso de laboratorio de meteorización acelerada. Se evaluaron sus propiedades físicas y mecánicas para determinar el efecto de la composición de las materias primas en la durabilidad del producto cerámico.

Palabras clave: resistencia a agentes atmosféricos, residuos, durabilidad, ladrillo cerámico.
SUMMARY

Over the past few decades, hundreds of papers have been published on the benefits of including rock powder as a raw material in fired clay brick manufacture. Very little has been written, however, about the durability and long-term behaviour of the final product. As a rule, the ceramic bricks used in construction in developing countries are fired at low temperatures, which detracts from their mechanical performance. This is particularly visible in harsh environmental conditions, where weathering causes severe deterioration. The present paper describes the impact of weathering on clay bricks containing from 0 to $10 \%$ granite powder, an industrial by-product. The specimens were fired at 500, 700 or $900{ }^{\circ} \mathrm{C}$ and subsequently exposed to natural environmental conditions or accelerated laboratory weathering. Their physical and mechanical properties were evaluated to determine the effect of the composition of raw materials on fired clay product durability.

Key words: weather resistance, waste, durability, clay brick.

(*) Universidade Estadual do Norte Fluminense "Darcy Ribeiro", Río de Janeiro (Brasil).

Persona de contacto/Corresponding author: gxavier@uenf.br 


\section{INTRODUCCIÓN}

Los productos cerámicos tienden a deteriorarse cuando entran en contacto con los elementos. En este contexto, se entiende por deterioro el efecto de los agentes atmosféricos sobre los productos cerámicos sin que se produzcan alteraciones cristalográficas.

Los principales procesos que afectan a la durabilidad de estos materiales de construcción son:

1) el deterioro de muros de ladrillo así como de losas y baldosas cerámicas, que da lugar a grietas y filtraciones (Figuras 1a y 1c);

2) el deterioro de las hiladas de fábrica inferiores por la absorción por capilaridad de agua sulfatada $\left(\mathrm{Na}_{2} \mathrm{SO}_{4}\right)$ (Figura 2a); y

3) el rápido deterioro de las piezas cocidas a bajas temperaturas (Figuras $2 b$ y $2 c$ ).

Se define alterabilidad como la vulnerabilidad de un producto cerámico ante el deterioro, mientras que la durabilidad es la capacidad de dichos productos para mantener su estabilidad estructural y su apariencia con el paso del tiempo. Así, la alterabilidad y la durabilidad dependen en gran medida del material, de las características ambientales y del tiempo de contacto con los elementos $(1,2)$.

En las regiones tropicales en las que existen grandes oscilaciones de temperatura y humedad, los agentes atmosféricos que afectan directamente a los productos cerámicos son:

\section{INTRODUCTION}

Burnt clay and ceramic products tend to decay when in contact with the elements. Decay in this context is therefore understood to be the effect of atmospheric agents on fired clay involving no crystallographic alterations.

The developments that shorten the durability of these construction materials include, primarily:

1) deterioration of brick walls and ceramic tile resulting in cracks and leaks (Figures 1a-1c);

2) decay in the lower rows of masonry due to the capillary uptake of water containing sodium sulfate $\left(\mathrm{Na}_{2} \mathrm{SO}_{4}\right)$ (Figure $\left.2 \mathrm{a}\right)$, and

3) rapid decay due to low firing temperatures (Figures $2 b$ and $2 c$ ).

Alterability is defined as the vulnerability of a fired clay product to decay, while durability is the capacity of such products to retain their structural stability and appearance over time. Therefore, alterability and durability depend heavily on the material, the environmental characteristics and exposure time $(1,2)$.

In tropical regions where temperature and humidity vary widely, the weathering agents that act directly on burnt clay are:
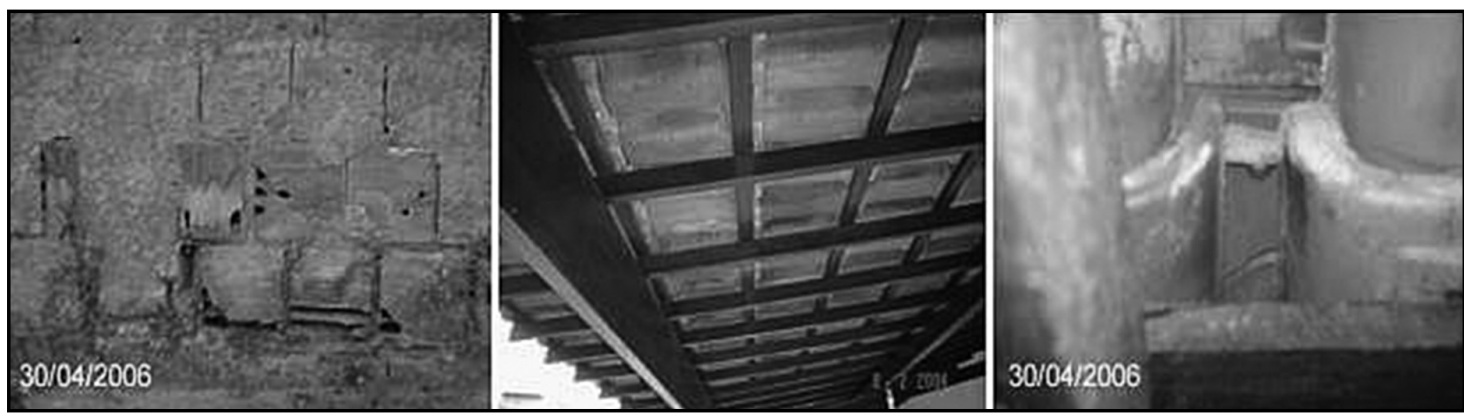

Figura 1. a) Meteorización acelerada en ladrillos; b) material cerámico afectado por hongos; c) grietas en azulejo cerámico. Figure 1. a) Rapid degradation in bricks; b) fungus spread out; and c) cracks in the tile ceramic.
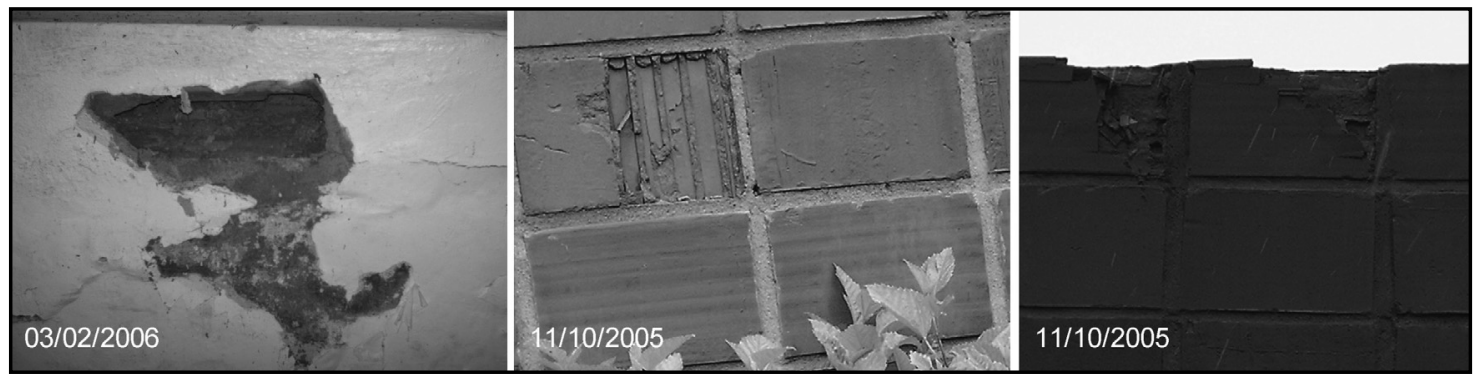

Figura 2. a) Degradación provocada por sulfatos; b) y c) exfoliación de ladrillos. Figure 2. a) Degradation due to sulfated water b) and c) brick raveling. 
- las precipitaciones y la humedad relativa;

- la insolación cíclica y las bruscas bajadas de temperatura, que provocan la contracción y dilatación de los materiales;

- las elevadas temperaturas ambientales, que favorecen las reacciones químicas; y

- el viento y la energía cinética, que provocan el deterioro por abrasión.

Los mecanismos que intervienen en el deterioro son los mismos que los que provocan la meteorización. La dilatación y la contracción resultantes de los cambios de temperatura y humedad pueden dar lugar a grietas y al deterioro que las acompaña (3).

Puede añadirse polvo de granito, que es un subproducto procedente del corte de la piedra ornamental, para mitigar los cambios no deseados en los productos cerámicos. Los residuos de granito tienen un elevado contenido de óxido alcalino, procedente de los abundantes feldespatos y minerales micáceos que componen este tipo de roca (4).

En algunos casos, los efectos provocados por la acción ambiental son graves. Varios investigadores han demostrado que la inclusión de residuos industriales en la pasta arcillosa resulta beneficiosa (5-8), ya que aumenta la resistencia al reducir la porosidad abierta. Sin embargo, se ha prestado poca atención a la durabilidad de estos materiales.

\section{EXPERIMENTAL}

La arcilla empleada en este estudio procedía de canteras situadas en Campos dos Goytacazes, al noreste del estado brasileño de Río de Janeiro. La empresa Cachoeiro de Itapemirim-ES, al sudeste de Brasil, una región con una producción mensual de piedra cortada de aproximadamente 150.000 toneladas, proporcionó el polvo de granito.

El Laboratorio de Mecánica del Suelo del LECIV/CCT/UENF desarrolló un programa experimental para evaluar las características físicas y mecánicas de las materias primas, así como la durabilidad de los productos cerámicos elaborados con residuos de granito.

Las materias primas se molieron y secaron en el laboratorio a $110^{\circ} \mathrm{C}$, y se pasaron a continuación por un tamiz del no $20(0,85 \mathrm{~mm})$. Después se separó una parte de dicho material, que se pasó por un tamiz del no 325 $(0,044 \mathrm{~mm})$ para su caracterización mediante difracción por rayos $X$ (arcilla y residuos), la determinación de su composición química (arcilla y residuos) y su caracterización medioambiental (residuos).

El análisis por DRX se realizó mediante el método del polvo con muestras de grano no orientado de $0,3 \mathrm{~g}$ en
- rainfall and relative humidity;

- cyclical insolation and abrupt declines in temperature, causing contraction and expansion;

- high ambient temperatures that favour chemical reactions; and

- wind and kinetic energy that induce abrasive decay.

The mechanisms involved in decay are the same as the actions that cause weathering. The expansion and contraction resulting from changes in temperature and humidity may induce cracking and concomitant deterioration (3).

Granite powder, a by-product of ornamental stone cutting, may be added to clay to reduce undesirable changes in fired clay products. Granite waste has a high alkaline oxide content, present in the abundant feldspars and micaceous minerals in this type of rock (4).

The effects provoked by environmental action are sometimes severe. Research has shown that the inclusion of industrial waste in clay paste is beneficial (58), for it raises strength by reducing the open porosity. Very little attention has been paid to the durability of these materials, however.

\section{EXPERIMENTAL}

The clay used in this study was supplied by local industries at Campos dos Goytacazes, in the north-eastern corner of the Brazilian state of Rio de Janeiro. The granite powder was provided by Cachoeiro de Itapemirim-ES in southeastern Brazil, a region whose cut stone output comes to approximately 150000 tonnes per month.

An experimental program was developed by the LECIV/CCT/UENF Soil Mechanics Laboratory to evaluate the physical and mechanical characteristics of the raw materials as well as the durability of fired clay products containing granite waste.

The raw materials were crushed and dried in the laboratory at $110^{\circ} \mathrm{C}$ and subsequently sieved in a no 20 $(0.85 \mathrm{~mm})$ mesh sieve. Part of the material was then separated and sieved in a no $325(0.044 \mathrm{~mm})$ mesh sieve for characterisation by $X$-ray diffraction (clay and waste), determination of the chemical composition (clay and waste) and environmental characterisation (waste only).

Powder X-ray diffraction was conducted on $0.3 \mathrm{~g}$ nonoriented samples in a Siemens D 5000 diffractometer. 
un equipo D 5000 de Siemens. La composición química se obtuvo mediante espectrometría de FRX realizada en un equipo Philips PW 2400 a pastillas de $10 \mathrm{~g}$ sometidas a presión. La pérdida por calcinación se halló determinando la diferencia de peso entre las muestras cocidas a $900^{\circ} \mathrm{C}$ y las desecadas a $110^{\circ} \mathrm{C}$. Para identificar la posible presencia de sustancias peligrosas en las muestras se aplicaron los métodos de lixiviación y solubilización descritos en las normas brasileñas NBR 10005, NBR 10006 y NBR 10004

Se prepararon muestras con arcilla y un 0 , un 5 y un $10 \%$ de polvo de granito (en adelante, $0 R, 5 R$ y $10 R$ ). El polvo granítico se pasó por un tamiz del no $20(0,85$ $\mathrm{mm}$ ). Los materiales se mezclaron en seco y se calculó la humedad de extrusión a partir de la ecuación [1] (9):
The chemical composition was obtained with $10 \mathrm{~g}$ pressed pellets via florescence spectrometry on a Philips PW 2400 facility. Loss on ignition was found by determining the difference in weight between samples fired at $900^{\circ} \mathrm{C}$ and the specimens dried at $110^{\circ} \mathrm{C}$. The leaching and solubilisation methods described in Brazilian standards NBR 10005, NBR 10006 and NBR 10004 were used to identify the possible presence of hazardous substances in the samples.

Samples were prepared for testing with clay and 0, 5 and $10 \%$ granite powder (hereafter $O R, 5 R$ and 10R). The waste powder was sieved in a no $20(0.85 \mathrm{~mm})$ mesh sieve. The dry materials were mixed and the extrusion moisture was calculated from Equation [1] (9):

$$
H_{\text {ext }}=\frac{\mathrm{LL}}{2}+2 \%
$$

siendo $\mathrm{LL}$ (10) el límite de líquido y $\mathrm{H}_{\mathrm{ext}}$ la humedad de extrusión.

Las mezclas se embutieron al vacío a una presión de $20 "$ de $\mathrm{Hg}$ y se colocaron en moldes prismáticos de $11,0 \times 2,7$ $x 1,7 \mathrm{~cm}$. Las probetas se secaron en un horno eléctrico a $110^{\circ} \mathrm{C}$ y luego se cocieron a 500, 700 o $900{ }^{\circ} \mathrm{C}$. La temperatura se aumentó a una velocidad de $5^{\circ} \mathrm{C} / \mathrm{min}$ hasta alcanzar las indicadas. Las probetas se mantuvieron a dichas temperaturas durante 3 horas en una atmósfera oxidante, dejándose enfriar posteriormente de forma natural a temperatura ambiente.

Tras la cocción, los ladrillos aparentemente intactos -aquellos en los que no se apreciaban imperfecciones- se sometieron a ensayos de variación linear y de resistencia a la flexión de tres puntos, según se describe en las normas $(11,12)$. Se llevaron a cabo cinco ensayos y se tomó el valor medio como resultado.

En el ensayo de resistencia a la flexión los tres puntos de apoyo se distanciaban a $9 \mathrm{~cm}$ entre sí y la carga se aumentó a una velocidad de $0,1 \mathrm{~mm} / \mathrm{min}$. Con este ensayo se pretendía determinar el índice de pérdida de resistencia a flexión $\left(\mathrm{I}_{\mathrm{RF}}\right)$, entendiendo por tal la evolución de la resistencia en función del tiempo de meteorización. Esta resistencia se calculó mediante la aplicación de la ecuación [2]:

$$
I_{F S}=\frac{F_{\text {intact }}-F_{\text {decayed }}}{F S_{\text {intact }}} \times 100 \%
$$

siendo FS la resistencia a flexión. Los subíndices intacto y deteriorado no precisan de explicación. where $L L(10)$ is the liquid limit and Wext is the extrusion moisture content.

The mixed samples were vacuum extruded under a pressure of 20" of $\mathrm{Hg}$ and placed in $11.0 \times 2.7 \times 1.7 \mathrm{~cm}$ prismatic moulds. The specimens were dried in an electric kiln at $110^{\circ} \mathrm{C}$ and then fired at 500, 700 or 900 ${ }^{\circ} \mathrm{C}$. The ramping rate was $5{ }^{\circ} \mathrm{C} / \mathrm{min}$. and the samples were fired for 3 hours at the target temperature in an oxidising atmosphere. They were subsequently allowed to cool naturally at laboratory temperature.

After firing, the apparently intact bricks (without no visible imperfections) were subjected to water absorption tests and the three-point load bending strength test described in $(11,12)$. The value used was the mean of five trials.

The three-point loading test was performed at a loading rate of $0.1 \mathrm{~mm} / \mathrm{min}$ with the supports spaced at $9.0 \mathrm{~cm}$. The objective sought with this test was to determine the flexural strength index $\left(I_{F S}\right)$, defined as the variation in strength versus weathering time and calculated from equation [2]: decayed are self-explanatory. 
La meteorización acelerada se realizó en un equipo especial desarrollado a tal fin en el LECIV/CCT/UENF (Figura 3) y se complementó con ciclos de humedad-secado. El equipo desarrollado se basa en el mismo principio que el extractor Soxhlet de uso habitual en la industria.

Este equipo permite controlar el ritmo tanto de humidificación de las probetas como de los cambios de temperatura. El líquido empleado fue agua destilada. Durante los ensayos se controló la calidad del agua y se renovó esta cuando se estimó oportuno.

Las probetas se colocaron en estantes metálicos en el interior de la cámara (véase la Figura 3) y se sometieron a cambios de temperatura mientras se rociaban periódicamente con agua caliente o fría para simular la lluvia. El mecanismo de humidificación consistía en el bombeo de agua destilada a través de rociadores situados en la parte superior del depósito, creando de esta forma una atmósfera de vapor saturado.
Accelerated weathering was conducted in special equipment developed for this purpose at LECIV/CCT/UENF (Figure 3) and supplemented with wet-dry cycles. The equipment developed is based on the same principle as the standard industrial Soxhlet extractor.

With this equipment, the operator can control the timing of both sample wetting and temperature changes. The liquid used was distilled water. In the trials, the water quality was monitored and refreshed as necessary.

The samples were placed on steel shelves inside the chamber (see Figure 3) and subjected to temperature variations while being periodically sprayed with hot and cold water to simulate rainfall. The wetting mechanism consisted of pumping distilled water through sprinklers located at the top of the tank, thereby creating a steamsaturated atmosphere.

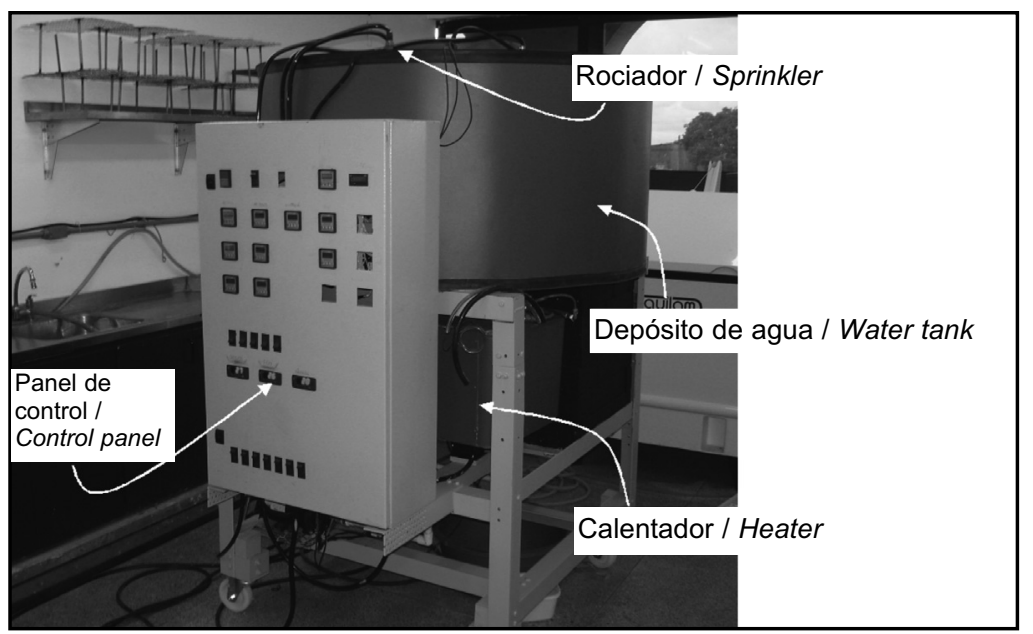

Figura 3. Equipo de meteorización acelerada del LECIV/CCT/UNEF. Figure 3. Equipment of degradation of the LECIV/CCT/UENF.

Primero se calentó el agua a unos $70^{\circ} \mathrm{C}$ y luego se dejó enfriar hasta unos $30^{\circ} \mathrm{C}$. Las probetas se meteorizaron de esta manera durante 300, 658 o 1.500 horas.

Los ensayos con ciclos de humedad-secado son habituales en los estudios de meteorización realizados a los áridos empleados en la construcción civil (13). En este ensayo, la duración mínima de cada ciclo (humidificación y secado en horno) queda definida por las curvas de saturación y secado, como las que se ven en las Figuras 4 y 5 . Puesto que en las primeras 6 horas de la prueba no se observó ningún cambio en los valores de masa iniciales durante el ciclo de humedad-secado, teniendo en cuenta la disponibilidad de los trabajadores de laboratorio solo en el periodo diurno los tiempos de saturación y secado (por debajo de $100^{\circ} \mathrm{C}$ ) se definieron, respectivamente, como de 8 y de 14 horas. Las probetas se sumergieron en un
The water was first heated to approximately $70{ }^{\circ} \mathrm{C}$ and then allowed to cool to around $30^{\circ} \mathrm{C}$. The samples were weathered in this manner for 300, 658 or 1500 hours.

Wet-dry cycle testing is commonly applied in weathering studies conducted on aggregates used in civil construction (13). In this test, the minimum duration of each cycle (wetting and kiln drying) is defined by saturation and drying curves such as shown in Figures 4 and 5. In this study, since no variation was observed in the initial mass values found during the wet-dry cycle in the first 6 hours, taking into account the availability of laboratory workers in the daytime only the saturation and drying (under $100^{\circ} \mathrm{C}$ ) times were defined to be 8 and 14 hours, respectively. The specimens were immersed in a 200 litre tank filled with distilled water kept at $21^{\circ} \mathrm{C}$ and a pH of 7. Two wet-dry 
depósito que contenía 200 litros de agua destilada que se mantuvieron a $21^{\circ} \mathrm{C}$ y con un $\mathrm{pH}$ de 7 . Se realizaron dos series de humedad-secado: una de 50 ciclos y otra de 150 ciclos.

El objeto de este procedimiento era comparar el deterioro acelerado de laboratorio con la meteorización natural. Las probetas se sometieron a deterioro natural durante 6, 8 y 10 meses (de enero a octubre), durante los cuales se hizo un seguimiento constante de la temperatura ambiente, la humedad relativa, la velocidad del viento, la precipitación y la radiación solar. Esta parte del experimento se realizó en terrenos del campus de la UENF, situado a $21^{\circ} 45^{\prime}$ de latitud sur, $41^{\circ} 18^{\prime}$ de longitud oeste y una altitud de $11 \mathrm{~m}$ sobre el nivel del mar.

Se hicieron micrografías MEB para evaluar la morfología y la textura tanto de las probetas intactas como de las sometidas a meteorización. La microestructura de la superficie externa de las probetas frescas y meteorizadas se determinó con un microscopio electrónico de barrido Zeiss DSM 962. Las muestras se recubrieron con oro para mejorar su conductividad eléctrica. Las condiciones empleadas para garantizar una valoración representativa y completa de los cambios microestructurales producidos series were used, one consisting of 50 and the other of 150 cycles.

This purpose of this procedure was to compare laboratory-accelerated decay to natural weathering. The specimens were subjected to natural decay for 6,8 or 10 months (January to October), during which time the ambient temperature, relative humidity, wind speed, precipitation and solar radiation were constantly monitored. This part of the procedure was carried out in the field at the UENF campus, which is located at $21^{\circ} 45^{\prime}$ south latitude, $41^{\circ} 18^{\prime}$ west longitude and at an altitude of $11 \mathrm{~m}$ above sea level.

SEM micrographs were made to evaluate the morphology and texture of both intact as the specimens subjected to weathering. The microstructure of the external surface of natural and weathered specimens was determined with a scanning electron microscope Zeiss 962 DSM. The samples were covered with gold to improve its electrical conductivity. The conditions used to ensure a representative and complete evaluation of the microstructural changes occurring during weathering

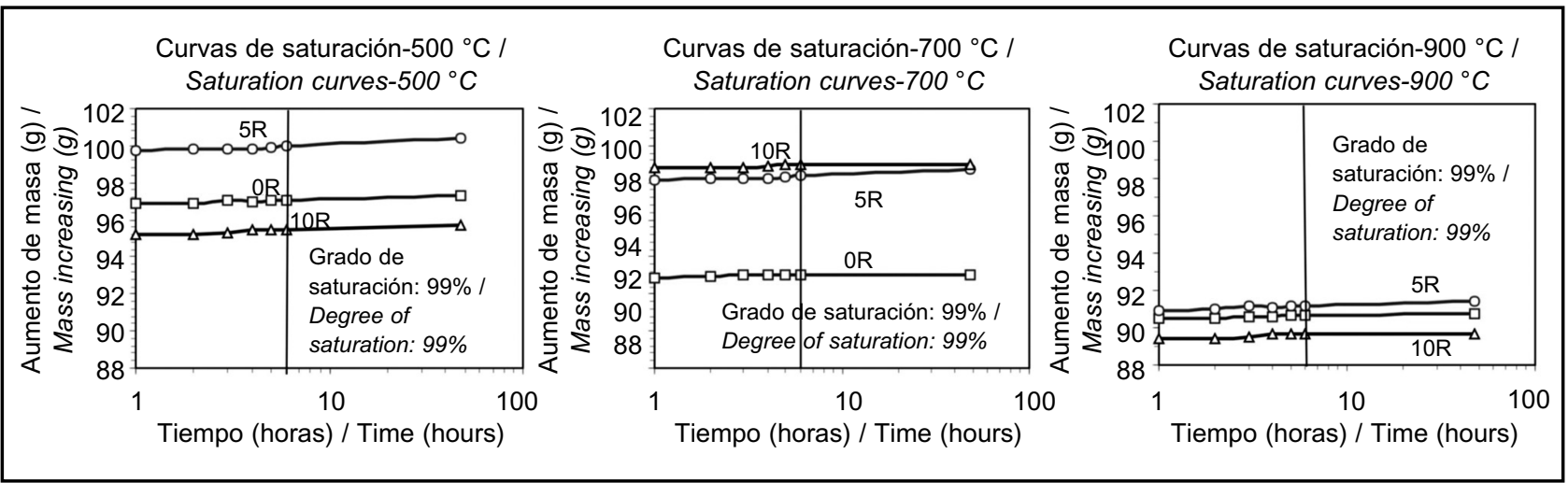

Figura 4. Saturación de los materiales sumergidos en agua destilada en función del tiempo de inmersión. Figure 4. Saturation curves for up to 48 saturation hours in distilled water.

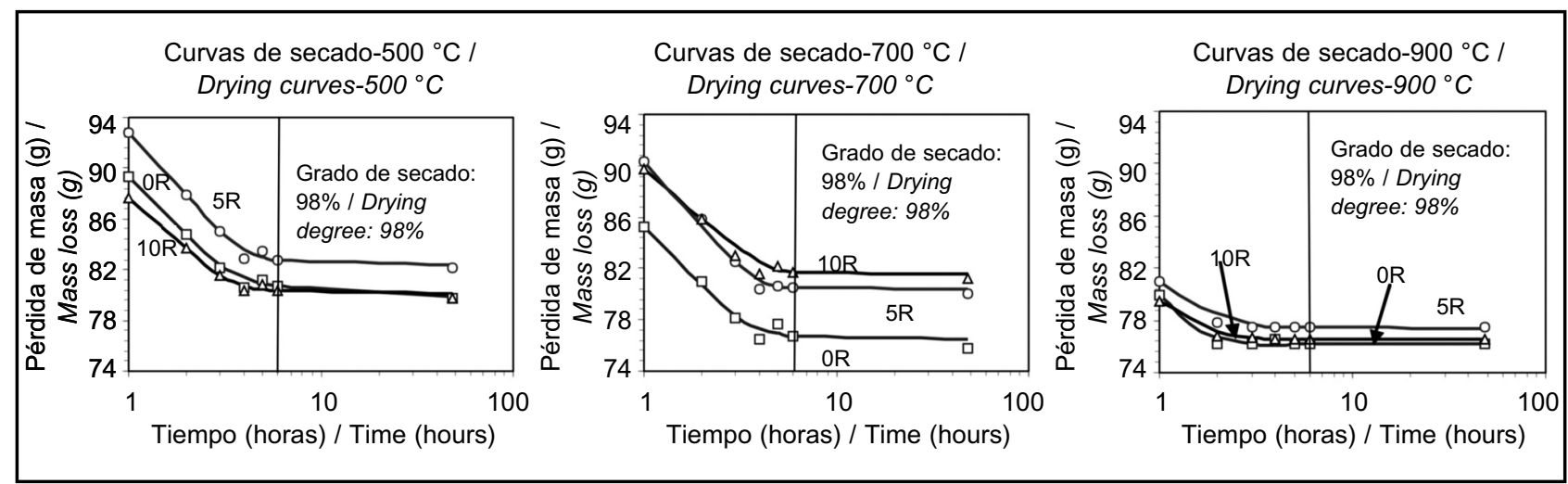

Figura 5. Secado de los materiales en horno a $110^{\circ} \mathrm{C}$ en función del tiempo durante más de 48 horas.

Figure 5. Drying curves up to 48 hours in oven at $110^{\circ} \mathrm{C}$. 
durante la meteorización fueron las siguientes: las probetas cocidas a $700{ }^{\circ} \mathrm{C}$ y con un 0 o un $5 \%$ de polvo de granito se meteorizaron mediante rociado durante 1.500 horas o se sometieron a 150 ciclos de humedad-secado.

\section{RESULTADOS Y DISCUSIÓN}

\subsection{Caracterización de las materias primas}

Los espectros de XRD de la arcilla y del polvo de granito se muestran en la Figura 6 . En el polvo de granito se detectaron muscovita $\left(\mathrm{KAl}_{2}\left(\mathrm{AlSi}_{8} \mathrm{O}_{10}\right)(\mathrm{OH})_{2}\right)$ y feldespato potásico (microclina: $\mathrm{KAISi}_{3} \mathrm{O}_{8}$ ), $\mathrm{y}$, en menor medida, anfibolita y calcita. La calcita estaba presente en los lodos abrasivos empleados en el corte del granito. El uso de lodos abrasivos con calcita, agua y hierro (granalla) es una práctica en Brasil.

En cuanto al análisis del suelo, los difractogramas indicaron la presencia de cuarzo, caolinita $\left(\mathrm{Al}_{2} \mathrm{O}_{3} \cdot 2 \mathrm{SiO}_{2} \cdot 2 \mathrm{H}_{2} \mathrm{O}\right.$ -mineral principal-) y feldespato como principales componentes, así como pequeñas cantidades de ilita, gibbsita $\left(\mathrm{Al}(\mathrm{OH})_{3}\right)$ y goetita $(\mathrm{FeO}(\mathrm{OH}))$.

En la Tabla 1 se enumeran los principales compuestos químicos identificados en la arcilla y el polvo de granito. De la cantidad de $\mathrm{SiO}_{2}$ (42,30\%) existente en la arcilla puede deducirse la presencia de minerales arcillosos como la caolinita $\left(\mathrm{Al}_{2} \mathrm{O}_{3} \cdot 2 \mathrm{SiO}_{2} .2 \mathrm{H}_{2} \mathrm{O}\right)$ y la ilita, así como were as follows: the specimens fired at $700^{\circ} \mathrm{C}$ and with 0 or $5 \%$ of granite waste by continuous leaching for 1500 hours or subjected to 150 wet-dry cycles.

\section{RESULTS AND DISCUSSION}

\subsection{Characterisation of the raw materials}

$X R D$ spectra for both the clay and the granite waste are shown in Figure 6. The granite waste was observed to contain muscovite $\left(\mathrm{KAl}_{2}\left(\mathrm{AlSi}_{8} \mathrm{O}_{10}\right)(\mathrm{OH})_{2}\right)$ and potassium feldspar (microcline: $\mathrm{KAISi}_{3} \mathrm{O}_{8}$ ), along with minor proportions of amphibolite and calcite. Calcite was present in the abrasive slurry used in cutting granite. The use of calcite abrasive slurries, water and metallic dust is a practice in Brazil.

The diffractograms for the soil, in turn, revealed the presence of quartz, kaolinite $\left(\mathrm{Al}_{2} \mathrm{O}_{3} \cdot 2 \mathrm{SiO}_{2} \cdot 2 \mathrm{H}_{2} \mathrm{O}\right.$-main mineral) and feldspar as the main components, while minor amounts of illite, gibbsite $\left(\mathrm{Al}(\mathrm{OH})_{3}\right)$ and goethite $(\mathrm{FeO}(\mathrm{OH}))$ were also observed.

Table 1 lists the main chemical compounds identified in the clay and the granite waste. The amount of $\mathrm{SiO}_{2}$ $(42.30 \%)$ in the clay sample denoted the presence of clay minerals such as kaolinite $\left(\mathrm{Al}_{2} \mathrm{O}_{3} \cdot 2 \mathrm{SiO}_{2} \cdot 2 \mathrm{H}_{2} \mathrm{O}\right)$ and illite, as well as of free quartz in the sample as a whole.

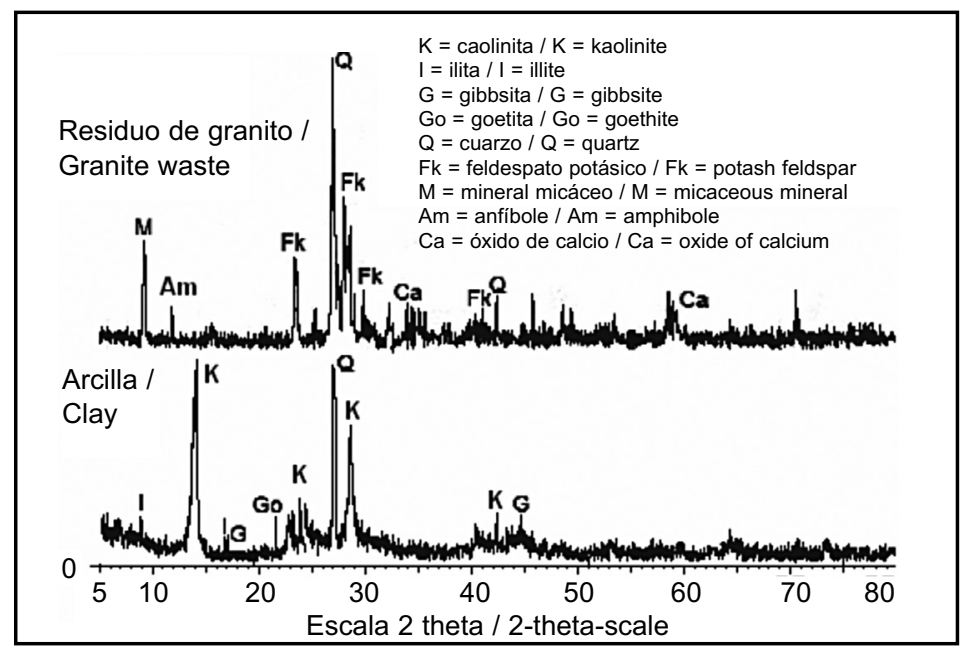

Figura 6. Espectros DRX de suelo arcilloso y residuo de granito.

Figure 6. X-ray spectra for the clayey soil and granite waste.

Tabla 1 / Table 1

Composición química de la arcilla y el residuo de granito (\%).

Chemical composition (\% out) of the clay and granite waste.

\begin{tabular}{|c|c|c|c|c|c|c|c|c|c|}
\hline Materiales / Materials & P.F. / Lol & $\mathbf{S i O}_{2}$ & $\mathrm{Al}_{2} \mathrm{O}_{3}$ & $\mathrm{Fe}_{2} \mathbf{O}_{3}$ & $\mathbf{C a O}$ & $\mathbf{M g O}$ & $\mathrm{Na}_{2} \mathbf{O}$ & $\mathrm{K}_{2} \mathbf{O}$ & $\mathrm{TiO}_{2}$ \\
\hline Arcilla / Clay & 15.40 & 42.30 & 32.00 & 6.87 & 0.20 & 0.70 & 0.04 & 0.94 & 1.24 \\
\hline Residuo de granito / Granite waste & 1.55 & 69.20 & 14.60 & 3.49 & 3.21 & 0.03 & 3.13 & 4.49 & 0.16 \\
\hline
\end{tabular}


de cuarzo libre en la probeta en su conjunto. $\mathrm{El} \mathrm{Al}_{2} \mathrm{O}_{3}$ (32\%) procedía principalmente del mineral arcilloso y de hidróxidos como la gibbsita $\left(\mathrm{Al}(\mathrm{OH})_{3}\right)$.

La elevada proporción $(6,87 \%)$ en la arcilla de $\mathrm{Fe}_{2} \mathrm{O}_{3}$, que desempeña el papel de fundente, dio al producto final un tono rojo oscuro tras la cocción. La presencia de un $0,98 \%$ de álcalis $\left(\mathrm{Na}_{2} \mathrm{O}+\mathrm{K}_{2} \mathrm{O}\right)$, que también son fundentes y formaban la fase líquida durante la cocción, estaba íntimamente relacionada con la disminución de la porosidad del material. El 1,24\% de $\mathrm{TiO}_{2}$, un tinte producto de la presencia de rutilo o anatasa (14), contribuyó al comportamiento refractario durante la cocción. El $15,40 \%$ de pérdida por calcinación (PC) de la arcilla representa la pérdida de agua libre, agua de adhesión y agua de constitución en la materia prima, así como la degradación de materia orgánica.

En el análisis químico del polvo de granito se detectó un contenido superior al $69 \%$ de sílice y de aproximadamente el $14 \%$ de $\mathrm{Al}_{2} \mathrm{O}_{3}$; es decir, una composición química básicamente idéntica a la de las rocas graníticas (cuarzo, feldespato y mica). El CaO $\left(3,21 \%\right.$ ) y el $\mathrm{Fe}_{2} \mathrm{O}_{3}$ $(3,49 \%)$ se atribuyeron a la presencia de partículas de hierro en los limos abrasivos empleados como agentes lubricantes y abrasivos durante el corte de la piedra.

Los óxidos de sodio y potasio $\left(\mathrm{Na}_{2} \mathrm{O}+\mathrm{K}_{2} \mathrm{O}\right)$ procedentes de los feldespatos y la mica, que suponían un $7,62 \%$ de estos residuos, actuaron como fundentes, mejorando la resistencia a la meteorización del material al rellenar parte de los huecos internos. Debido a su estabilidad estructural inherente, la pérdida por calcinación del residuo fue relativamente pequeña $(1,55 \%)$, atribuyéndose principalmente al deterioro de la mica.

Una comparación de los análisis químicos realizados a la arcilla empleada en este experimento (Tabla 1) y los recogidos en la literatura para otras arcillas empleadas en la fabricación de ladrillos $(4,9,15)$ confirmó que aquella era adecuada para la elaboración de productos cerámicos. Según Vieira et al. (3), Ferreira et al. (7) y Neves et al. (8), los residuos de granito también son adecuados como adición en los materiales cerámicos.

\subsection{Caracterización ambiental de los residuos de granito}

En la Tabla 2 se muestran los resultados de los ensayos de lixiviación.

Las concentraciones de los elementos detectados en las muestras se encontraban por debajo de los límites fijados por la Norma brasileña NBR 10005, por lo que se consideró el material como no tóxico. Además, dado que el pH del lixiviado se mantuvo en todo momento entre el 5,15 inicial y el 9,4 final, se clasificó como no corrosivo, según esa misma norma.
The origin of the $\mathrm{Al}_{2} \mathrm{O}_{3}$ (32\%) was primarily the clay mineral and hydroxides such as gibbsite $\left(\mathrm{Al}(\mathrm{OH})_{3}\right)$.

The high (6.87\%) proportion of $\mathrm{Fe}_{2} \mathrm{O}_{3}$, a flux, in the clay was what gave the end product its dark red hue after firing. The presence of $0.98 \%$ of alkalis $\left(\mathrm{Na}_{2} \mathrm{O}+\mathrm{K}_{2} \mathrm{O}\right)$, also fluxes, which formed the liquid phase during firing, was closely associated with the decline in material porosity. The $1.24 \%$ of $\mathrm{TiO}_{2}$, a dye, the result of the presence of rutile or anatase (14), contributed to the refractory behaviour during firing. At $15.40 \%$, the loss on ignition (LOI) in the clay denoted the loss of free, bound and chemically combined water in the raw material and the degradation of organic matter.

The chemical analysis of the granite waste, in turn, showed that its silica content was over $69 \%$ and that the fraction of $\mathrm{Al}_{2} \mathrm{O}_{3}$ amounted to about $14 \%$, i.e., a chemical composition that is much the same as in granite rocks (quartz, feldspar and mica group minerals). The $\mathrm{CaO}(3.21 \%)$ and $\mathrm{Fe}_{2} \mathrm{O}_{3}(3.49 \%)$ were attributed to the iron pellet-containing abrasive sludge used as a lubricant and abrasive agent during stone cutting.

The $7.62 \%$ sodium and potassium oxides $\left(\mathrm{Na}_{2} \mathrm{O}+\mathrm{K}_{2} \mathrm{O}\right)$ detected in this waste, resent in the feldspars and mica, acted as fluxes and enhanced the weather-resistance of the material by filling part of the internal voids. The fairly small $(1.55 \%)$ LoI in the waste was due to its inherent structural stability and attributable primarily to mica degradation.

A comparison of the results of the chemical analysis of the clay used here (Table 1) and the findings reported in the literature for other brick-making industry clays (4, 9, 15) showed that the former is apt for manufacturing ceramic products. According to Vieira et al. (3), Ferreira et al. (7) and Neves et al. (8), granite waste is likewise suitable as an additive in burnt clay materials.

\subsection{Environmental characterisation of granite waste}

The results of the leaching test are given in Table 2.

Inasmuch as the concentrations observed for all the elements identified in the samples were below the ceilings set out in Brazilian Standard NBR 10005, the material was regarded as non-toxic. Moreover, since the $\mathrm{pH}$ of the leachate ranged at all times from 5.15 (initial) to 9.4 (final), it was classified as noncorrosive, likewise further to Brazilian Standard NBR 10005. 
Tabla 2 / Table 2

Condiciones y resultados del ensayo de lixiviación del residuo de granito. Results and conditions of the leaching tests.

\begin{tabular}{|c|c|c|c|c|c|}
\hline $\begin{array}{c}\text { Elemento químico / } \\
\text { Chemical element }\end{array}$ & $\begin{array}{c}\text { Residuo de granito / } \\
\text { Granite waste (mg/l) }\end{array}$ & $\begin{array}{c}\text { Lixiviación máxima } \\
\text { permitida / Maximum } \\
\text { limits leaching (9) } \\
\text { (mg/l) }\end{array}$ & $\begin{array}{c}\text { Condiciones del } \\
\text { ensayo / Condition of } \\
\text { Lab Test }\end{array}$ & $\begin{array}{c}\text { Residuo de granito / } \\
\text { Granite waste (mg/l) }\end{array}$ & $\begin{array}{c}\text { Lixiviación máxima } \\
\text { permitida / Maximum } \\
\text { limits leaching (9) } \\
\text { (mg/l) }\end{array}$ \\
\hline $\mathrm{Ag}$ & $<0.005$ & 5.000 & $\mathrm{pH}$ inicial / initial $\mathrm{pH}$ & 9.400 & $\mathrm{NE} / \mathrm{NS}$ \\
\hline $\mathrm{Cd}$ & $<0.002$ & 0.500 & $\mathrm{pH}$ final/ final pH & 5.150 & $\mathrm{NE} / \mathrm{NS}$ \\
\hline $\mathrm{Cr}$ & 0.020 & 5.000 & $\begin{array}{c}\text { Vol. Ácido / } \\
\text { Acid Vol. (ml) }\end{array}$ & 80 & $\mathrm{NE} / \mathrm{NS}$ \\
\hline $\mathrm{Pb}$ & 0.030 & 5.000 & Tiempo / Time (h) & 28 & $\mathrm{NE} / \mathrm{NS}$ \\
\hline $\mathrm{Ba}$ & 0.110 & 100.00 & & & \\
\hline
\end{tabular}

NE: no especificado / NS: Not Specified.

Los resultados de los ensayos de solubilidad se presentan en la Tabla 3. La solubilidad de todos los productos químicos que se incluyen en la tabla fue inferior a los límites máximos establecidos en la Norma brasileña NBR 10004, a excepción del Pb (plomo), cuya solubilidad fue ligeramente superior a la permitida. Por este motivo, el residuo se tipificó como clase II (no inerte), debido principalmente a la presencia de partículas de hierro en los lodos abrasivos empleados en el corte de la piedra.

Los resultados obtenidos en este estudio concuerdan con otros anteriores $(8,16)$, en los que los residuos de granito se tipificaron como no tóxicos, no corrosivos y no inertes (clase II).
Table 3 gives the solubility test findings. The solubility of all the chemicals listed in the table was lower than the maximum limits laid down in Brazilian standard NBR 10004, with the exception of $\mathrm{Pb}$ (lead), whose solubility was slightly higher than the ceiling. By that measure, the waste would be classified as class II, not inert, primarily due to the presence of the iron pellets used as an abrasive in stone cutting.

The results obtained in this study are consistent with findings reported previously $(8,16)$, in which granite waste was observed to be a non-toxic, non-corrosive and not inert material (class II).

Tabla 3 / Table 3

Resultados del ensayo de solubilidad del residuo de granito.

Results of the solubility test.

\begin{tabular}{|c|c|c|}
\hline Elemento químico / Chemical element & Residuo de granito / Granite waste (mg/l) & $\begin{array}{c}\text { Solubilización máxima permitida / Maximum } \\
\text { limits solubilized (mg/l) (10) }\end{array}$ \\
\hline $\mathrm{Ag}$ & $<0.005$ & 0.050 \\
\hline $\mathrm{Cd}$ & $<0.002$ & 0.005 \\
\hline $\mathrm{Cr}$ & $<0.020$ & 0.050 \\
\hline $\mathrm{Pb}$ & $<0.060$ & 0.050 \\
\hline $\mathrm{Ba}$ & $<0,020$ & 1.000 \\
\hline $\mathrm{Al}$ & 0.150 & 0.200 \\
\hline $\mathrm{Cu}$ & $<0.010$ & 1.000 \\
\hline $\mathrm{Fe}$ & 0.030 & 0.300 \\
\hline $\mathrm{Mn}$ & $<0.010$ & 0.100 \\
\hline $\mathrm{Zn}$ & $<0.003$ & 5.000 \\
\hline $\mathrm{Na}$ & 33.800 & 200.000 \\
\hline Cloruros / Clorets & 9.440 & 250.000 \\
\hline Dureza / Hardness & 19.900 & 500.000 \\
\hline Sulfatos / Sulphates & 11.170 & 400.000 \\
\hline
\end{tabular}




\subsection{Variación lineal de las dimensiones (VL) y del índice dela resistencia a la flexión (IFS)}

La Figura 7 presenta la variación lineal de las dimensiones de las probetas en función del tiempo, tanto de los materiales meteorizados de forma natural como los que se sometieron a envejecimiento acelerado. De acuerdo con esta figura, el aumento de la variación dimensional con el tiempo de meteorización era independiente de la temperatura, del procedimiento de meteorización y de la cantidad de residuos de granito añadidos a la pasta arcillosa.

\subsection{Linear variation (LV) and flexural strength index (IFS)}

Figure 7 shows the rate of linear variation in sample dimensions over time for the materials weathered both naturally and by accelerated laboratory ageing. The figure reveals that the rise in linear variation with weathering time was independent of temperature, weathering procedure and the amount of granite waste added to the clay paste.

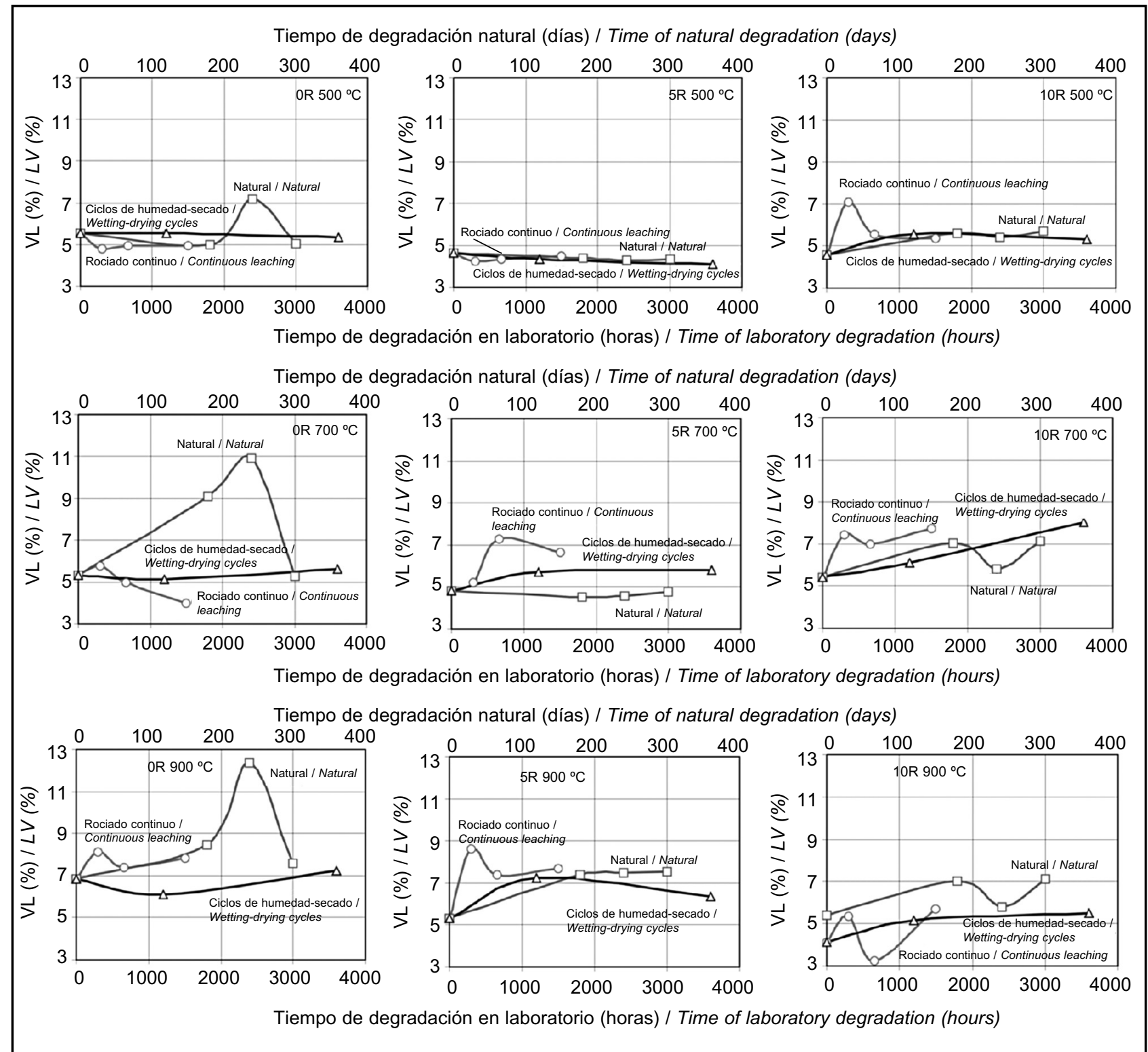

Figura 7. Efecto de los tres procedimientos de meteorización sobre la variación lineal de las dimensiones de las probetas con un 0 , un 5 o un $10 \%$ de residuo de granito y cocidas a 500,700 o $900{ }^{\circ} \mathrm{C}$.

Figure 7. Effect of the different degradation procedures in the lineal variation of the samples with addition of granite waste for firing temperatures of 500,700 and $900{ }^{\circ} \mathrm{C}$. 


\subsubsection{Ensayo de rociado continuo}

Las dimensiones lineales variaron en torno al 3\% en relación con las probetas intactas (líneas rojas) en las tres etapas del ciclo de meteorización. El tramo inicial de las curvas (periodo inicial) refleja la VL provocada por la cocción, tras la cual la pieza se contrajo o dilató independientemente de su contenido de residuos. La variación dimensional del material meteorizado de forma natural que contenía un $0 \%$ de residuos de granito fue, aproximadamente, del $4 \%$.

De las probetas rociadas con agua, la mayor contracción en el tiempo siempre se observó en las de tipo 10R, a todas las temperaturas de cocción. Las probetas con residuos de granito que se cocieron a mayores temperaturas tendieron a contraerse más, incluso en presencia del agua destilada utilizada en los ensayos de rociado.

Las probetas sin residuos de granito cocidas a 500 y $700{ }^{\circ} \mathrm{C}$ tendieron a dilatarse tras su rociado con agua en la cámara de curado, probablemente debido a la humedad que aún contenían estas probetas a dichas temperaturas.

Además, la presencia de ciertos minerales alcalinos ( $\mathrm{CaO}$ + MgO, Tabla 1) tanto en la arcilla como en el polvo de granito puede haber contribuido a la dilatación en presencia de agua, ya que dichos minerales pueden haber provocado una recristalización.

\subsubsection{Ciclos de humedad-secado}

Como se puede ver en la Figura 7, las curvas de variación lineal de los materiales cocidos a 500 y $700{ }^{\circ} \mathrm{C}$ fueron parecidas hasta los ciclos 50 y 150 , y que la dilatación que presentó la muestra con un $5 \%$ de residuos de granito fue mínima. Hasta los 150 ciclos, la variación lineal de los ladrillos cocidos a $900{ }^{\circ} \mathrm{C}$ evolucionó de forma similar a las piezas cocidas a las otras temperaturas, aunque en los primeros 50 ciclos las probetas $0 R$ cocidas a esta $900^{\circ} \mathrm{C}$ se dilataron, mientras que las probetas $5 R$ y $10 \mathrm{R}$ se contrajeron.

\subsection{Meteorización natural}

Los valores de VL de las probetas intactas tras 6 y 10 meses de meteorización natural fueron muy parecidos: se observó una mayor contracción en las probetas $\mathrm{OR}$ cocidas a todas las temperaturas que en las probetas $5 R$ y $10 R$. Aunque se detectó una dilatación de poca envergadura en las muestras $0 \mathrm{R}$ cocidas a $500{ }^{\circ} \mathrm{C}$ en todo el ensayo, los valores se mantuvieron bastante estables.

La Figura 7 muestra VL superiores al $10 \%$ en las probetas OR cocidas a $700{ }^{\circ} \mathrm{C}$ a los 8 meses y un brusco descenso

\subsubsection{Continuous spray test}

The linear dimensions were observed to vary by about $3 \%$ with respect to the intact samples used (red lines) at the three stages of the weathering cycle. The initial branch of the curves (initial time) reflects firing-induced $L V$, after which the fired clay body either contracted or expanded with time, regardless of the waste content. The variation in naturally weathered material with $0 \%$ waste was about $4 \%$.

Greater contraction over time was observed in the sprayed $10 R$ samples prepared at all firing temperatures. The specimens containing granite waste that had been fired at higher temperatures tended to contract more, even in the presence of the distilled water used in the spraying trials.

The samples with zero waste fired at 500 and $700{ }^{\circ} \mathrm{C}$ tended to expand after spraying in the curing chamber, more than likely because of the moisture in the $O R$ samples fired at those temperatures.

In addition, the presence of certain alkaline minerals $(\mathrm{CaO}+\mathrm{MgO}$, Table 1) in both the clay and the waste powder may have contributed to expansion in the presence of water, for they may have induced recrystallisation.

\subsubsection{Wet-dry cycles}

Figure 7 shows that the linear variation curves in materials fired at 500 and $700{ }^{\circ} \mathrm{C}$ were similar up to 50 and 150 cycles, and that expansion in the sample with $5 \%$ waste was minimal. Up to 150 cycles, the linear variation in bricks fired at $900{ }^{\circ} \mathrm{C}$ also followed a similar pattern, although in the first 50 cycles, the OR samples fired at this temperature expanded, while the $5 R$ and 10R samples contracted.

\subsection{Natural weathering}

The $L V$ values for the intact samples after 6 and 10 months of natural weathering were highly similar: greater contraction was observed in the $O R$ samples (than in the $5 R$ and 10R specimens) fired at all the temperatures used in this study. Although minor expansion was found in the $500{ }^{\circ} \mathrm{C}$ OR samples throughout the trial, the values remained fairly steady.

Figure 7 shows LVs of over $10 \%$ in the $O R 700{ }^{\circ} \mathrm{C}$ samples after 8 months, with an abrupt decline after 
tras 10 meses, momento en el que se observaron valores próximos a los obtenidos con las muestras intactas. Este comportamiento puede explicarse por la elevada intercambiabilidad catiónica de la caolinita y metacaolinita en la fase amorfa cuando el material se cuece a $700^{\circ} \mathrm{C}$, razón por la que el material habría interactuado con la humedad del aire, dilatándose, para luego contraerse a medida que se fuera secando.

Este puede ser el motivo de la exfoliación observada en algunos muros de fábrica, que lleva a su debilitamiento con el paso del tiempo. Las dos principales causas de la exfoliación son, por una parte, el impedimento horizontal y vertical que supone el mortero y, por otra, el autoconfinamiento de los ladrillos que, al no poder dilatarse en estas dos direcciones, "crecen" en la única vía libre, es decir, en la dirección perpendicular a la cara del material.

Los efectos de las grietas por dilatación y contracción pueden observarse también en las baldosas rojas, aunque no estén sometidas a grandes cargas (véase la Figura 1c).

\section{5. Índice de resistencia a flexión $\left(\mathrm{I}_{\mathrm{Fs}}\right)$}

En la Figura 8 se aprecia la evolución a lo largo del tiempo del índice de resistencia a flexión ( $\mathrm{I}_{\mathrm{FS}}$ ) de las probetas meteorizadas tanto de forma natural como en el laboratorio.

Como puede verse en la figura, a todas las temperaturas de cocción y todos los porcentajes de residuos de granito, el índice de resistencia a flexión ( $\mathrm{I}_{\mathrm{FS}}$ ) evolucionó de forma similar en ambos procedimientos de meteorización.

Esto indica que la influencia de la temperatura de cocción sobre la evolución de dicho índice con el tiempo fue mínima en los dos procedimientos. Por el contrario, sí se vio afectada de forma significativa por el procedimiento de meteorización, aunque su comportamiento fue independiente del contenido de residuo granítico.

\subsubsection{Ensayo de rociado continuado}

En la Figura 8 puede verse asimismo que el $\mathrm{I}_{\mathrm{RF}}$ señaló un descenso considerable de la resistencia mecánica de las probetas tras su rociado, en especial de las probetas cocidas a 500 y $700{ }^{\circ} \mathrm{C}$. Esto se debería a que dichas temperaturas de cocción serían insuficientes para garantizar una cohesión total entre las partículas.

Al comparar las probetas $0 R$ con las de tupo $5 R$ y $10 R$, se observa que la evolución de la pérdida de resistencia de las probetas rociadas con agua era similar dentro de cada temperatura de cocción, lo que indica que la presencia o ausencia del polvo de granito en la pasta tenía escasa consecuencia en este ensayo.
10 months, when the values were observed to be close to the findings for the intact samples. The explanation for this behaviour may be found in the high cationic exchangeability of the kaolinite or meta-kaolinite in the amorphous phase when the material is fired at $700{ }^{\circ} \mathrm{C}$. As a result, the material would interact with the moisture in the air and expand, contracting as it dried.

This may underlie the spalling observed in some brick walls, which weakens the wall over time. The two basic reasons for spalling are, on the one hand, the horizontal and vertical restraint exerted by the mortar, and on the other the self-confinement of the bricks which, unable to expand in these two directions, "grow" in the sole degree of freedom left, i.e., the direction normal to the face of the material.

The effects of expansion and shrinkage cracks can be observed in red tile as well, even where not subjected to heavy loads (see Figure 1c).

\subsection{Flexural strength index $\left(I_{F S}\right)$}

Figure 8 shows the changes in the flexural strength index (I $\left.I_{F S}\right)$ over time for the samples exposed to both natural and laboratory (accelerated) weathering.

As the figure shows, the flexural strength index $\left(I_{F S}\right)$ curves for each waste percentage series followed similar patterns across the entire range of firing temperatures, in both weathering procedures.

This indicates that firing temperature had scant impact on the variation in the flexural strength index with exposure time in either of the procedures used. By contrast, which was used, although it was also independent of the waste content.

\subsubsection{Continuous spray test}

Figure 8 likewise shows that the $I_{F S}$ denoted a substantial decline in specimen mechanical strength after continuous spraying, particularly in the samples fired at 500 and $700{ }^{\circ} \mathrm{C}$. The reason would be that these firing temperatures were not high enough to ensure full inter-particle cohesion.

The pattern of strength loss in the sprayed samples was similar within each firing temperature, comparing the $O R$ to the $5 R$ and $10 R$ curves, an indication that the presence or otherwise of waste powder in the paste was of scant consequence in this test. 


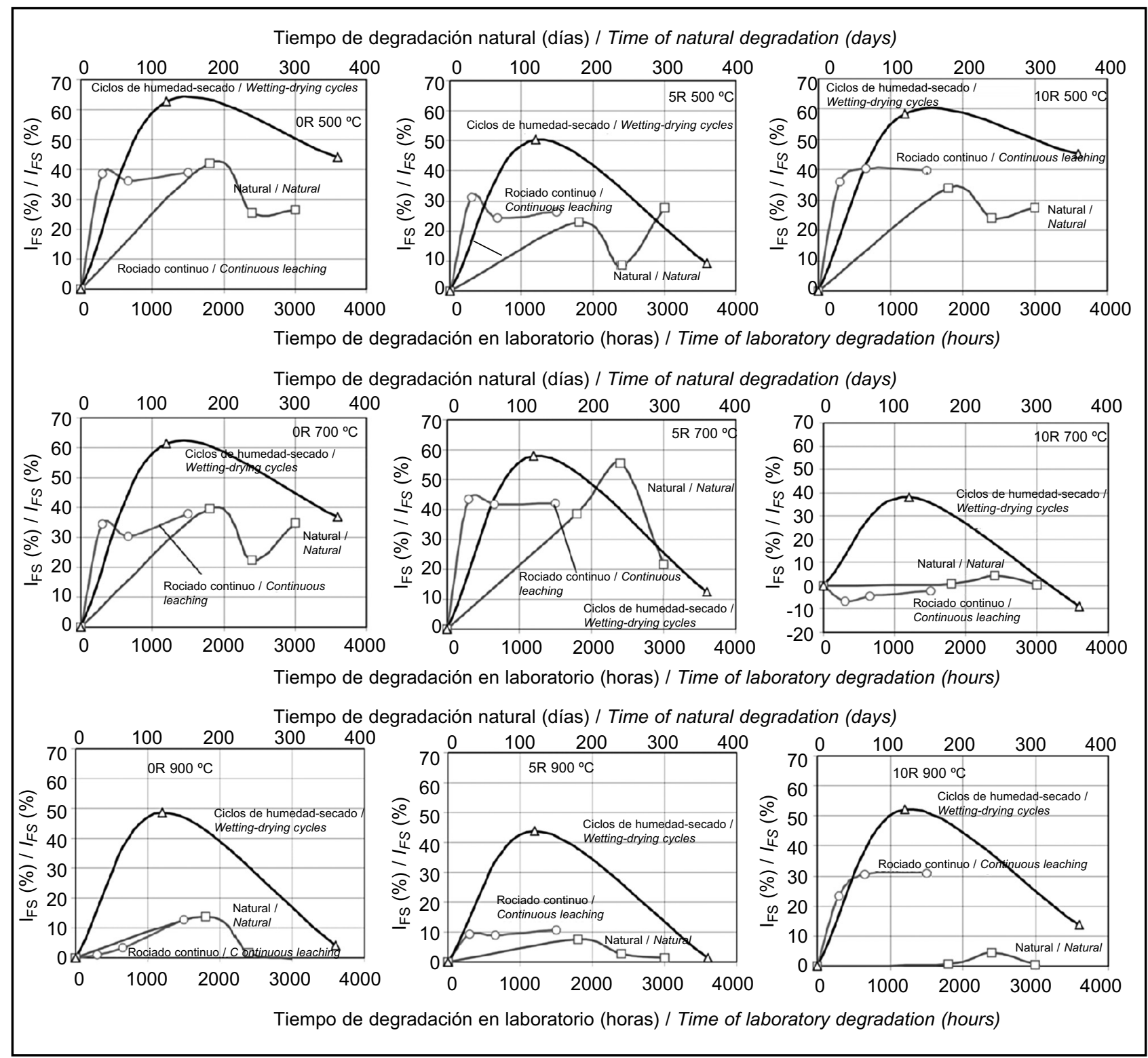

Figura 7. Efecto de los tres procedimientos de meteorización sobre la variación lineal de las dimensiones de las probetas con un 0 , un 5 o un $10 \%$ de residuo de granito y cocidas a $500,700 \circ 900^{\circ} \mathrm{C}$.

Figure 7. Effect of the different degradation procedures in the lineal variation of the samples with addition of granite waste for firing temperatures of 500,700 and $900{ }^{\circ} \mathrm{C}$.

Los valores medios de resistencia a flexión de las probetas cocidas a $900{ }^{\circ} \mathrm{C}$ no presentaron diferencias significativas entre sí en los gradientes de reducción, aunque la resistencia se redujo en menor medida a lo largo de todo el ensayo en las probetas con un $5 \%$ de polvo de granito, con independencia del procedimiento de meteorización empleado.

\subsubsection{Ciclos de humedad-secado}

La pérdida de resistencia fue especialmente pronunciada en las probetas sometidas a menos de 50 ciclos, mientras que las que se sometieron a 150 ciclos recuperaron
The mean flexural strength values for specimens fired at $900{ }^{\circ} \mathrm{C}$ exhibited no significant differences in the reduction gradient, although strength declined less in the samples containing 5\% granite powder throughout the trial and regardless of the weathering procedure.

\subsubsection{Wet-dry cycles}

Strength loss was particularly acute in the samples exposed to under 50 cycles, while the 150-cycle specimens recovered a significant portion of that loss. 
una parte significativa de lo perdido. Después de la meteorización, las probetas $5 \mathrm{R}$ mostraron una mayor resistencia mecánica que las probetas $\mathrm{OR}$, con independencia de la temperatura de cocción.

\subsubsection{Meteorización natural}

En la Figura 8 se representan, además, los valores del $\mathrm{I}_{\mathrm{FS}}$ de las probetas $0 R, 5 R$ y $10 R$ cocidas a temperaturas entre 500 y $900{ }^{\circ} \mathrm{C}$ y sometidas a meteorización natural. En estas condiciones, las probetas mostraron el mayor descenso de su resistencia a flexión a los 6 meses, pero recuperaron resistencia a partir de los 8 meses. La explicación puede deberse a que los poros del material se encontraran obstruidos por agua durante este periodo de tiempo. A los 10 meses, las probetas $0 R$ y $10 R$ apenas se vieron afectadas. Tras 8 meses, las probetas $5 R$ recuperaron resistencia, aunque esta volvió a verse mermada tras completarse los 10 meses del ensayo.

No se hallaron diferencias significativas en las probetas cocidas a $900{ }^{\circ} \mathrm{C}$, fuera cual fuera su contenido de residuo de granito, señal de la existencia de una fuerte cohesión entre los granos plaquiformes que garantiza la resistencia de estos materiales ante el deterioro debido a la acción atmosférica. El hecho de que los valores de resistencia observados en las probetas $5 R$ fueran más altos que en los otros dos tipos de muestras a esta temperatura de cocción, demuestra que añadir residuos de granito contribuye de forma importante a mantener la resistencia, incluso durante el proceso de meteorización natural.

\subsection{Microestructura}

Se hicieron micrografías MEB para evaluar la morfología y la textura tanto de las probetas intactas como de las sometidas a meteorización. Las condiciones empleadas para garantizar una valoración representativa y completa de los cambios microestructurales producidos durante la meteorización fueron las siguientes: las probetas cocidas a $700{ }^{\circ} \mathrm{C}$ y con un 0 o un $5 \%$ de polvo de granito se meteorizaron mediante rociado durante 1.500 horas o se sometieron a 150 ciclos de humedad-secado.

La Figura 9 contiene una imagen MEB de una probeta intacta cocida a $700^{\circ} \mathrm{C}$. Obsérvese que la textura es más lisa y la porosidad más baja que la superficie de las probetas que se ven en las Figuras 10 y 11. La micrografía de la Figura 10, de una probeta rociada con agua, presenta grietas y una textura superficial rugosa, así como partículas sueltas que pueden interpretarse como un signo evidente de meteorización. Estas grietas y esta porosidad abierta son aún más visibles en las probetas sometidas a ciclos de humedad-secado, lo que concuerda con el aumento del $\mathrm{I}_{\mathrm{FS}}$ (Figura 8).
The $5 R$ samples fired at all three temperatures exhibited higher mechanical strength after weathering than the $O R$ samples.

\subsubsection{Natural weathering}

Figure 8 also plots the $I_{F S}$ values for the $0 R, 5 R$ and $10 R$ samples fired at 500 to $900{ }^{\circ} \mathrm{C}$ and exposed to natural weathering. Under these conditions, the samples exhibited the greatest decline in flexural strength after 6 months, while regaining strength after eight months. The explanation is believed to be that the material pores would be water-clogged during this period of time. After 10 months, the $O R$ and $10 R$ samples remained practically unaffected. After 8 months, the $5 R$ samples regained strength, followed by a loss after 10 months.

No significant differences were found in the samples fired at $900^{\circ} \mathrm{C}$ regardless of the waste content, revealing considerable cohesion among plate-like grains and guaranteeing their resistance to environmental decay. The higher strength values observed in the $5 R$ samples at this firing temperature showed that adding waste contributed considerably to retaining strength even while natural weathering was still taking place.

\subsection{Microstructure}

Scanning electron micrographs were taken for a morphological and textural evaluation of the intact and weathered samples. The conditions used to ensure a representative and comprehensive assessment of the micro-structural changes during weathering were as follows: samples fired at $700{ }^{\circ} \mathrm{C}$ and containing 0 or $5 \%$ granite powder were spray-weathered for 1500 hours or exposed to 150 wet-dry cycles.

Figure 9 contains an SEM image for an intact sample fired at $700{ }^{\circ} \mathrm{C}$. Note the smooth texture and low porosity compared to the surface of the samples depicted in Figures 10 and 11. The micrograph in Figure 10 reveals cracks and a rough surface texture in the sprayed sample, as well as loose particles that can be interpreted as a clear sign of weathering. These cracks and open porosity are even more obvious in the samples exposed to wet-dry cycles, which is consistent with an increase in $I_{F S}$ (Figure 8). 


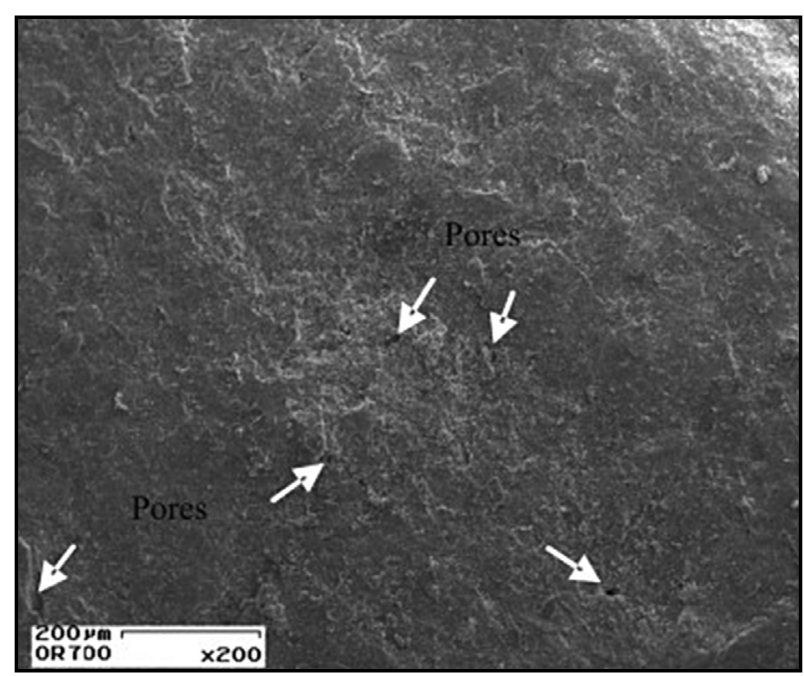

Figura 9. Microscopía electrónica de barrido de una probeta intacta, sin residuo de granito y cocida a $700^{\circ} \mathrm{C}$.

Figure 9. Scanning electron microscopy image for intact sample with no waste content fired at $700{ }^{\circ} \mathrm{C}$.

En la Figura 12 se ve un detalle de las características asociadas a las probetas intactas que contenían un $5 \%$ de polvo de granito. Aunque pueden verse algunos poros de mayor tamaño, la textura superficial parece ser más lisa que en la probeta de la Figura 9.

Una comparación de las Figuras 10 y 13, en las que se muestran probetas cocidas a $700{ }^{\circ} \mathrm{C}$ con un 0 y un $5 \%$ de residuo de granito, respectivamente, tras 1.500 horas de rociado con agua, permite constatar que los signos de meteorización son menos intensos en la segunda probeta, lo que indica una mayor durabilidad. Pueden llegarse a conclusiones parecidas al comparar las Figuras 11 y 14.

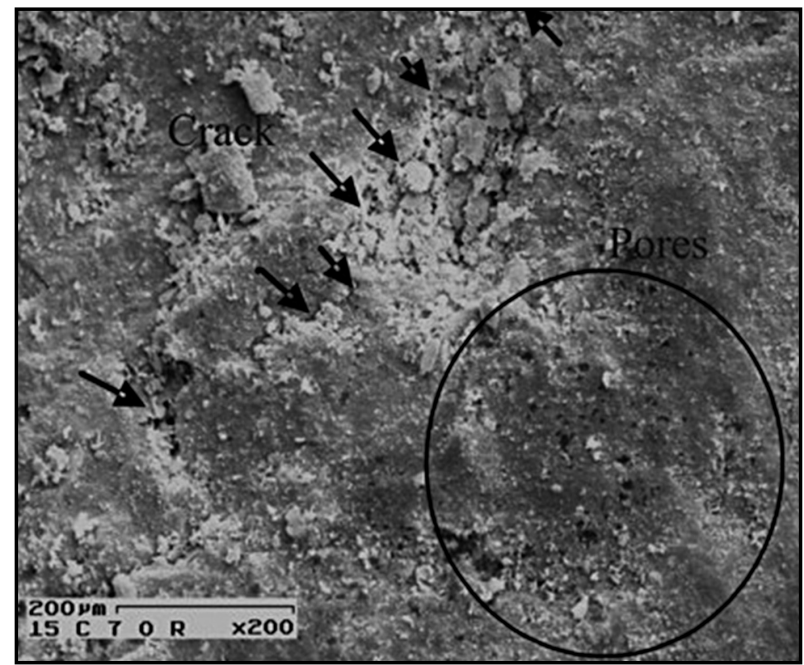

Figura 11. Microscopía electrónica de barrido de una probeta cocida a $700^{\circ} \mathrm{C}$ tras 150 ciclos de humedad-secado.

Figure 11. Scanning electron microscopy image for samples fired at $700^{\circ} \mathrm{C}$ after 150 wet-drying cycles.

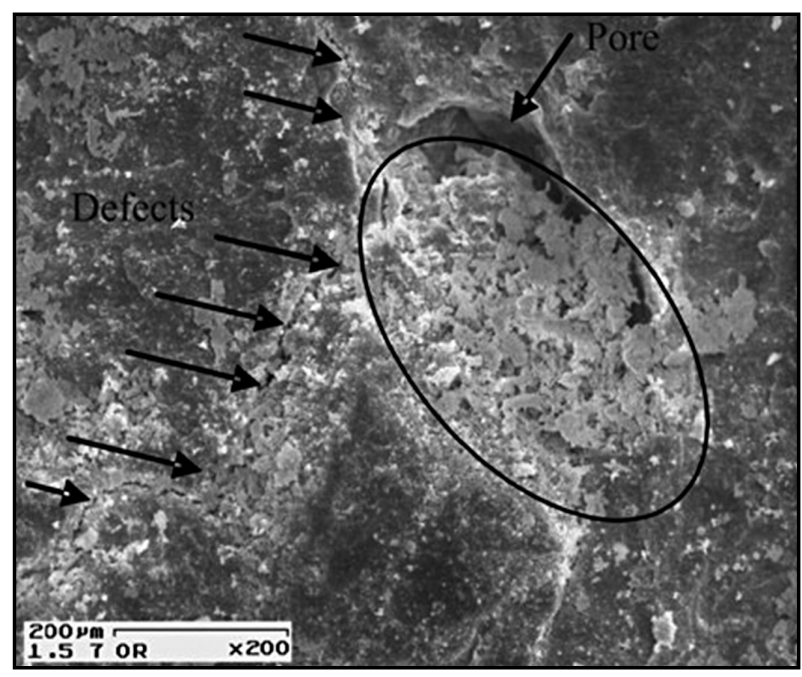

Figura 10. Microscopía electrónica de barrido de una probeta cocida a $700{ }^{\circ} \mathrm{C}$ tras 1.500 horas de meteorización por rociado con agua.

Figure 10. Scanning electron microscopy image for samples fired at $700{ }^{\circ} \mathrm{C}$ after 1500 hours of leaching.

Figure 12 shows a detail of the features associated with intact samples containing $5 \%$ granite powder, where although a few larger pores are visible, the surface texture appears to be smoother than in the Figure 9 sample.

A comparison of Figures 10 and 13, showing samples fired at $700{ }^{\circ} \mathrm{C}$ with 0 and $5 \%$ granite waste, respectively, after 1500 hours of spray treatment, revealed that the signs of weathering were less intense in the sample with the latter, an indication of greater durability. Similar conclusions may be drawn in connection with Figures 11 and 14.

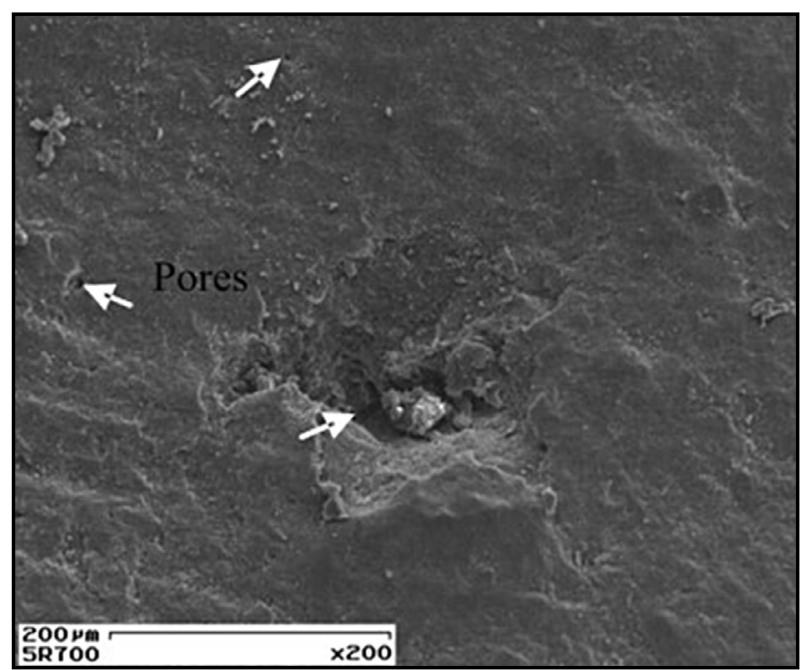

Figura 12. Microscopía electrónica de barrido de una probeta intacta, con un $5 \%$ de residuo de granito y cocida a $700^{\circ} \mathrm{C}$. Figure 12. Scanning electron microscopy image for intact sample with $5 \%$ of waste content, fired at $700{ }^{\circ} \mathrm{C}$. 


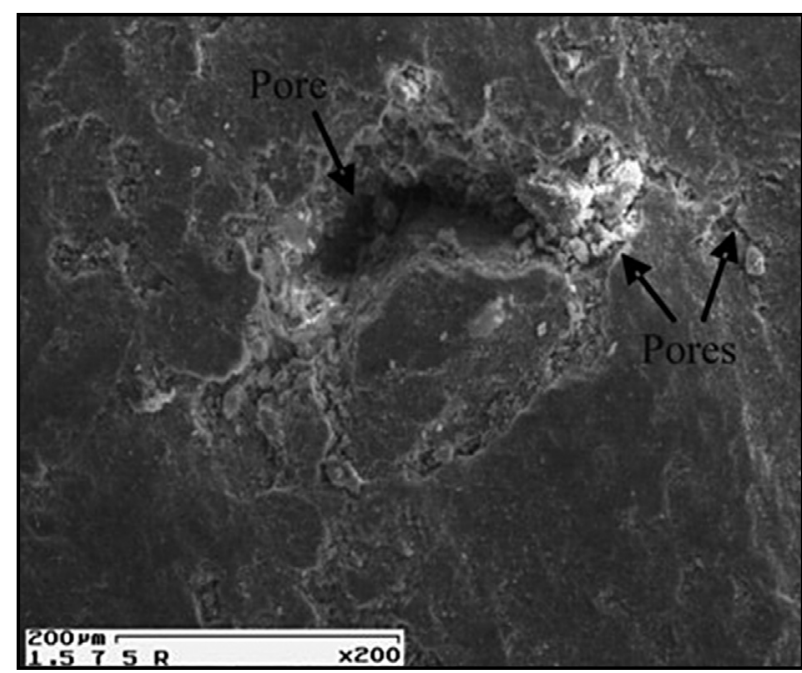

Figura 13. Microscopía electrónica de barrido de una probeta con un $5 \%$ de residuo de granito cocidas a $700{ }^{\circ} \mathrm{C}$ tras 1.500 horas de meteorización por rociado con agua.

Figure 13. Scanning electron microscopy image for samples with $5 \%$ of waste content fired at $700{ }^{\circ} \mathrm{C}$ after 1500 hours of leaching.

\section{CONCLUSIONES}

En este artículo se describe un exhaustivo estudio del comportamiento de material cerámico con unos contenidos del 0 , el 5 o el $10 \%$ de residuo de granito, cocido a 500, 700 o $900{ }^{\circ} \mathrm{C}$, y sometido a meteorización acelerada o natural. Su objetivo principal era evaluar los mecanismos físicos asociados a la respuesta mecánica de las probetas.

Los ciclos de humedad-secado de laboratorio demostraron ser idóneos para las probetas cocidas a 500 y $700^{\circ} \mathrm{C}$. Para las muestras cocidas a $900{ }^{\circ} \mathrm{C}$, sin embargo, este procedimiento de meteorización acelerada resultó más agresivo que la natural, ya que se obtuvieron índices de (pérdida) de resistencia a flexión (es decir, pérdida de resistencia) del $70 \%$.

Una comparación entre las variaciones lineales de las probetas (intactas o sometidas a meteorización) que contenían residuo de granito confirmó la influencia de las acciones ambientales en propiedades como la contracción, la dilatación y la pérdida de resistencia.

Aunque se observó que la meteorización, tanto natural como acelerada, aumentaba la heterogeneidad del material, no se pudo apreciar ninguna pauta clara.

Se ha visto que la incorporación de polvo de granito en el material arcilloso desempeña una importante función en la mejora de la durabilidad en la arcilla cocida. El parámetro que mayor impacto pareció tener en la resistencia a la meteorización fue la temperatura de cocción, en tanto en cuanto contribuye a la estabilidad del material ante la acción del ambiente.

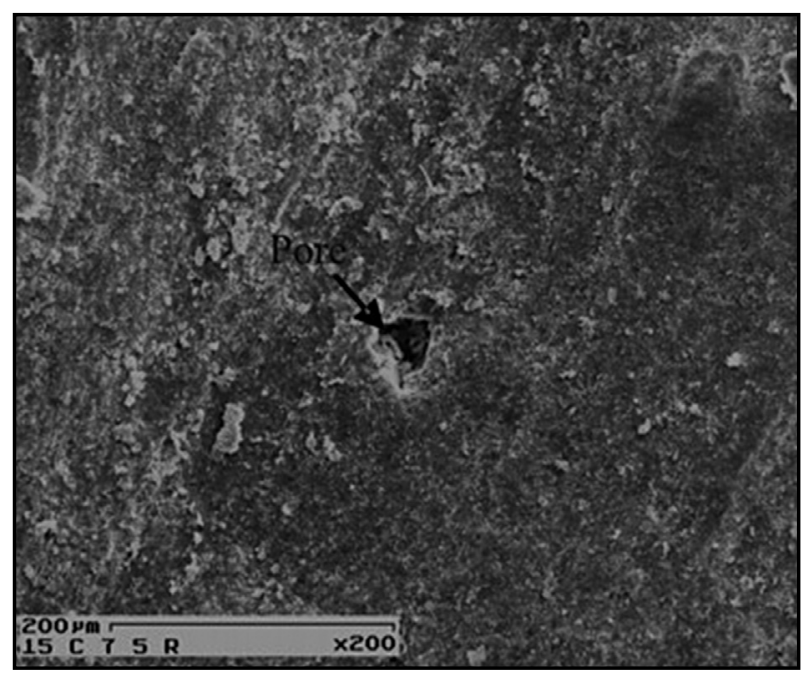

Figura 14. Microscopía electrónica de barrido de una probeta con un $5 \%$ de residuo de granito cocidas a $700{ }^{\circ} \mathrm{C}$ tras 150 ciclos de humedad-secado.

Figure 14. Scanning electron microscopy Image for samples with $5 \%$ of waste content fired at $700^{\circ} \mathrm{C}$ after 150 wet-drying cycles.

\section{CONCLUSIONS}

This paper describes a comprehensive study of the behaviour of fired clay material containing 0, 5 or $10 \%$ granite waste, fired at 500, 700 or $900{ }^{\circ} \mathrm{C}$ and exposed to accelerated or natural weathering. It aimed primarily to assess the physical mechanisms associated with the mechanical response of the samples.

The laboratory wet-dry cycles proved to be appropriate for the samples fired at 500 and $700{ }^{\circ} \mathrm{C}$. For the $900{ }^{\circ} \mathrm{C}$ samples, however, this accelerated ageing procedure was more rigorous than natural weathering, with flexural strength indices (i.e., strength loss) of $70 \%$.

A comparison between the linear variations in intact and weathered specimens containing granite waste verified the effect of environmental actions on properties such as contraction, expansion and loss of strength.

Both accelerated and natural field weathering were observed to increase material heterogeneity, although with no specific pattern.

The addition of granite powder was found to play an important role in enhancing the durability of red fired clay. Firing temperature was the parameter observed to have the greatest impact on weather resistance, insofar as it contributes to material stability when exposed to environmental actions. 


\section{AGRADECIMIENTOS}

Este estudio fue financiado por FAPERJ (Rio de Janeiro Research Council).

\section{ACKNOWLEDGEMENTS}

The present study was funded by FAPERJ (Rio de Janeiro Research Council).

\section{BIBLIOGRAFÍA / BIBLIOGRAPHY}

(1) Xavier, G. C.: "Resistência, Alterabilidade e Durabilidade de Peças Cerâmicas Vermelhas Incorporadas com Reíduo de Granito", Ph.D. Thesis (2006), Department of Civil Engineering, State University of Norte Fluminense Darcy Ribeiro, Campos dos Goytacazes, Rio de Janeiro, Brazil (in Portuguese).

(2) Maia, P. C. A.: "Avaliação do Comportamento Geomecânico e de Alterabilidade de Enrocamentos", Ph.D. Thesis (2001), Department of Civil Engineering, Catholic University of Rio de Janeiro, Rio de Janeiro, Brazil (in Portuguese).

(3) Frasca, M. H. B. O.: "Durabilidade e alterabilidade de rochas ormamentais e para revestimento", Revista Rocha de Qualidade, no 180 (2005), pp. 178-188 (in Portuguese).

(4) Vieira, C. M. F.; Soares, T. M.; Sánchez, R.; Monteiro, S. N.: "Incorporation of granite waste in red ceramics", Materials Science and Engineering A, no 373 (2004), pp. 115-121. http://dx.doi.org/10.1016/j.msea.2003.12.038

(5) Domínguez, E. A.; Ullmann, R.: "'Ecological bricks' made with clays and steel dust pollutants", Applied Clay Science, no 11 (1996), pp. 237-249. http://dx.doi.org/10.1016/S0169-1317(96)00020-8

(6) Darweesh, H. H. M.: "Building materials from siliceous clay and low grade dolomite rocks", Ceramics International, n 27 (2000), pp. 45-50. http://dx.doi.org/10.1016/S0272-8842(00)00040-7

(7) Ferreira, H. S.; Neves, G. A.; Ferreira, H. C.; Silva, M. C.: "Reciclagem de Resíduos Industriais Provenientes de Serragem de Granitos para uso na Composição de Massa para Confecção de Revestimentos Cerâmicos", in Proc 45th Brazilian Congress of Ceramic (2001), Florianopolis-SC, Brazil, pp. 1-12 (in Portuguese).

(8) Neves, G. A.: "Reciclagem de Resíduos da Serragem de Granitos para Uso como Matéria-Prima Cerâmica", Ph.D. Thesis (2002), Federal University of Campina Grande, Campina Grande, Paraíba, Brazil (in Portuguese).

(9) Alexandre, J.: "Análise de Matéria-Prima e Composições de Massa Utilizada em Cerâmica Vermelha", Ph.D. Thesis (2000), Department of Civil Engineering, State University of Norte Fluminense Darcy Ribeiro, Campos dos Goytacazes, Rio de Janeiro, Brazil (in Portuguese).

(10) Maia, P. C. A., Pinheiro, A. D.; Alexandre, J.: "Red Ceramic Materials Durability Evaluation", Materials Science Forum, vol. 498 (99) (2005), pp. 681-690. http://dx.doi.org/10.4028/www.scientific.net/MSF.498-499.681

(11) ASTM C 373 (American Society Tecnology Materials): "Standard Test Method for Water Absorption, Bulk Density, Apparent Porosity and Apparent Specific Gravity of Fired Whiteware Products" (1977a).

(12) ASTM C 674 (American Society Tecnology Materials): "Standard Test Method for Flexural Properties of Ceramic Whiteware Materials" (1977b).

(13) ABNT (Associação Brasileira de Normas Técnicas). "Solo -Determinação do Limite de Liquidez" (1984), NBR 6459.

(14) Toledo, R.: "Técnicas Fototérmicas e de Raios-X para o Monitoramento de Sólidos e Gases em Materiais Cerâmicos", Ph.D. Thesis (2003), State University of Norte Fluminense Darcy Ribeiro, Campos dos Goytacazes, Rio de Janeiro, Brazil (in Portuguese).

(15) Souza Santos, P.: Ciência e Tecnologia das Argilas, 3a ed., São Paulo, Editora Edgard Blucher Ltda, vol. 1 (1992), 499 pp. (in Portuguese).

(16) Silva, S. A. C.: "Caracterização de Resíduo da Serragem de Blocos de Granito. Estudo Potencial de Aplicação na fabricação de Argamassas de Assentamento e de Tijolos de Solo-Cimento", M.Sc. Thesis (1998), Federal University of Espírito Santo, Brazil (in Portuguese). 